\title{
Prophenoloxidase and Immune Indices of Indian WhiteShrimp Fenneropenaeus Indicus
}

Jeyachandran Sivakamavalli, Perumal Rajakumaran and Baskaralingam Vaseeharan*

Department of Animal Health and Management, Alagappa University, Karaikudi, India

\begin{abstract}
Economical importance of shrimp in aquaculture and to the increase of diseases that are threatening shrimp cultivation, leads to the necessity of studies on immune system of shrimp and are receiving increased attention. The Prophenoloxidase (ProPO) system is the origin of melanin production and considered to be an innate defence mechanism in invertebrates. In crustaceans, prophenoloxidase (ProPO) is present in the haemolymph as an inactive form of phenoloxidase. The present study focuses on the phenoloxidase activity and other innate immune responses such as agglutination activity, phagocytic activity and encapsulation, were studied from the haemocytes of Indian white shrimp Fenneropenaeus indicus. The PO activity of $F$. indicus showed highest titre value $(0.022 \pm 0.001)$ in plasma, with increased concentration of laminarin. $F$. indicus haemocytes showed the strongest agglutination titre against human erythrocytes $A(45 \pm 5.5)$ and yeast Saccharomyces cereviceace. The results of phagocytic activity showed ingestion of yeast $S$. cereviceace by haemocytes of $F$. indicus and the encapsulation showed highest response against the sepharose 6CLB beads than other DEAE and CM sepharose beads. The present study supplements the knowledge on crustacean immunity, and understands the host pathogen interactions. An advance made through immunological research is an important criteria to increase the yield, food production and also helps for the development of aqua farming.
\end{abstract}

Keywords: Agglutination; Encapsulation; F. indicus; Prophenoloxidase

\section{Introduction}

Fenneropenaeus indicus is one of the commercially important species in aquaculture along the Indian Ocean especially in east coast of India. Though, farming of the species faces lot of problems due to the occurrence of opportunistic microbial pathogens including bacteria and viruses [1-5]. Nowadays understanding the immune ability of shrimp and their defence mechanisms have become a primary concern in shrimp culture for better production. Invertebrate immune mechanism has the ability to recognize the invading organisms as foreign substance [6-8], these substances were recognized by pathogenassociated molecular patterns (PAMPs) such as lipopolysaccharide, peptidoglycan and glucan, present on the surface of microorganisms, which trigger the cellular and humoral responses in crustaceans 22 [9]. Cellular mediated responses include encapsulation, phagocytosis and nodule formation [10], whereas the humoral responses include the clotting cascade pathway, antimicrobial peptides synthesis, proPO cascade [10-12].

Crustaceans haemocytes comprises of important immune recognition components such as $\mathrm{PO}$, lipopolysaccharide $\beta-1,3$ glucan binding protein (LGBP) and agglutinins etc. Prophenoxidase proenzyme activity has been demonstrated in plasma haemocytes or in both [6,13-16]. Activation of ProPO system is triggered by LGBP through a complex cascade of native serine proteases and other factors $[16,17]$. Number of haemocytes mediated immune responses were studied, among that proPO system, when triggered, generates immunologically active substances such as opsonins, cytotoxic molecules $[16,18]$. Activation of haemocytes in arthropods is enhanced by microbial cell wall components, which also increases the phagocytic activity of haemocytes against bacteria or erythrocytes $[19,20]$. However, ProPo activating immune system has been well studied against foreign particles entry, there is no information at the cellular level regarding the F. indicus immune responses. The defence mechanism of $F$. indicus is poorly understood, but knowledge of this is an indispensable key for the development of current strategies to control infections in the Indian white shrimp culture. Hence, the present study reports the functional studies of Prophenoloxidase and the immune indices in Indian white shrimp Fenneropenaeus indicus.

\section{Materials and Methods}

\section{Animals}

Indian white shrimp Fenneropenaeus indicus used in the study were obtained from a commercial farm in Tamil nadu, India. They were acclimated at $26 \pm 1^{\circ} \mathrm{C}$ and a salinity of $20 \mathrm{ppt}$ in tanks with recirculating water in the laboratory. The body weight of the intermoult shrimp ranged from 11.1 to $14.0 \mathrm{~g}$ with an average of $12.5 \pm 1.5 \mathrm{~g}$ (mean \pm S.D.). During the acclimation period, the shrimp were fed a formulated shrimp diet (Shinta Feed Company, Pingtung, Taiwan) twice daily.

\section{Total haemocyte count}

One hundred microlitres of whole haemolymph were mixed with $100 \mathrm{ml}$ of marine anticoagulant (MAC, $0.1 \mathrm{M}$ glucose, $15 \mathrm{mM}$ trisodium citrate, $13 \mathrm{mM}$ citric acid, $50 \mathrm{mM}$ EDTA, $0.45 \mathrm{M}$ sodium chloride, $\mathrm{pH}$ 7.5).This haemocyte suspension was then fixed with $100 \mathrm{ml}$ paraformaldehyde $(4 \% \mathrm{w} / \mathrm{v})$. The number of haemocytes per millilitre was estimated using an Improved Neubauer haemocytometer. The numbers and relative proportions of haemocyte types were calculated using a minimum number of 250 cells/slide.

${ }^{*}$ Corresponding author: Dr. B. Vaseeharan, Department of Animal Health and Management, Alagappa University, Karaikudi 630 003, Tamil Nadu, India, Tel: +91 4565 225682/228079 - 96; Fax: +91 4565 225202, E-mail: vaseeharanb@gmail.com

Received June 28, 2012; Accepted August 13, 2012; Published August 23, 2012

Citation: Sivakamavalli J, Rajakumaran P, Vaseeharan B (2012) Prophenoloxidase and Immune Indices of Indian White Shrimp Fenneropenaeus Indicus. J Aquacult Res Dev 3:148 doi:10.4172/2155-9546.1000148

Copyright: ( 2012 Sivakamavalli J, et al. This is an open-access article distributed under the terms of the Creative Commons Attribution License, which permits unrestricted use, distribution, and reproduction in any medium, provided the original author and source are credited. 


\section{Assay of phenoloxidase (PO) enhancing activity}

In PO enhancing activity, haemocyte lysate was serially diluted twofold with $\mathrm{TBS} / \mathrm{Ca}^{2+}(\mathrm{pH} 7.4)$ buffer in flat-bottomed microtitre plates and incubated with $25 \mu \mathrm{l}$ of laminarin $(1 \mathrm{mg} / \mathrm{ml}$ in TBS-I, pH 7.4) for 1 $\mathrm{h}$ at room temperature [21]. $25 \mu \mathrm{l}$ of L- $\beta$-3, 4-dihydroxyphenylalanine (L-DOPA, $3 \mathrm{mg} / \mathrm{ml}$ in distilled water) was added and again incubated for $1 \mathrm{~h}$ at room temperature. Controls were made with Tris buffer saline buffer instead of haemocyte lysate, replacing them with TBS/Ca ${ }^{2+} \mathrm{pH}$ 7.4 buffers. The absorbance at $490 \mathrm{~nm}$ was measured at $30 \mathrm{~min}$ intervals using a Biophotometer Plus (Eppendorf, Germany) and expressed as units' min $^{-1}$ mg protein ${ }^{-1}$.

\section{Agglutination activity}

Haemo agglutination assay (HA) with erythrocytes (RBC): Blood samples of Human (A, B and O group) originate from healthy male volunteers (age 25-45 years), mouse and rat were obtained by venous or cardiac puncture and collected in sterile Alsever's solution [22]. Trypsin treatment and subsequent fixation of human A RBC with formalin were performed as described earlier [23]. Prior to HA assays, human RBC were washed three times with $0.9 \%$ saline, once with TBS-II $(25$ $\mathrm{mM}$ Tris HCL, $100 \mathrm{mM} \mathrm{NaCl}, \mathrm{pH}$ 7.5), and finally resuspended in the same buffer as $1.5 \%(\mathrm{v} / \mathrm{v})$ suspensions. HA assays were performed in V-bottom microtiter plates (Tarsons, Kolkata) by serial dilution of a 25 $\mu \mathrm{l}$ suspension with an equal volume of TBS II. RBC suspension $(25 \mu \mathrm{l})$ was added to each well, mixed, and incubated for $45 \mathrm{~min}$ at $26^{\circ} \mathrm{C}$. The HA titers were recorded as the reciprocal of the highest dilution of the sample causing complete agglutination of RBC. Control for all assays consisted of the substitution of the sample by TBS-II. Each experiment was performed in duplicate with at least for test samples and based on the median HA titer values. Necessity of the divalent cations for HA activity and EDTA sensitivity of haemolymph was described [23].

Yeast agglutination assay: In agglutination activity, baker's yeast was used as an indicator. Briefly, $25 \mu$ of plasma serially diluted twofold in TBS-I buffer (50 mM Tris $\mathrm{HCl}, 100 \mathrm{mM} \mathrm{Nacl}, 100 \mathrm{mM} \mathrm{CaCl}$, $\mathrm{pH}$ 7.5) in the wells of V-bottomed microtitre plates, then an equal volume of yeast solution (1\% made up in TBS-I, pH 7.4) was added and incubated at room temperature for 1 to $2 \mathrm{~h}$. Titres were documented as the reciprocal of the highest dilution showing agglutination judged microscopically. Control consisted of TBS I buffer, instead of plasma.

Agglutination inhibition assays: The substances to be tested for inhibition were dissolved in TBS-III $(10 \mathrm{mM}$ Tris $\mathrm{HCl}, 70 \mathrm{mM} \mathrm{Nacl}$, $100 \mathrm{mM} \mathrm{CaCl}_{2}, \mathrm{pH} 7.5$ ) (carbohydrates, $0.2 \mathrm{M}-0.8 \mathrm{M}$ ) or in TBS-IV (10 $\mathrm{mM}$ Tris HCL, $100 \mathrm{mM} \mathrm{Kcl}, 100 \mathrm{mM} \mathrm{CaCl}$, $\mathrm{pH}-8.2$ ) (glycoproteins 30 $\mathrm{mg} / \mathrm{ml}$ ). If necessary, the $\mathrm{pH}$ was adjusted to 7.8 using concentrated $\mathrm{NaOH}$ solution. Plasma to be tested $(25 \mu \mathrm{l})$ was serially diluted with an equal volume of the effluent sample in microtiter plates and incubated for $30 \mathrm{~min}$ at room temperature. Mouse RBC suspension $(25 \mu \mathrm{l})$ was added to each well and incubated for $30 \mathrm{~min}$ at room temperature. The minimal concentration of the test substance was completely inhibited and it's HA activity also recorded. Each assay was repeated for 5 times. Agglutinating inhibition activity was tested with the use of 21 carbohydrates (11 monosaccharides, 5 oligosaccharides and 5 polysaccharides).

\section{Phagocytosis}

In vitro phagocytosis assays were performed by engulfing foreign substances with haemocytes in suspension following Arumugam et al. [24]. Briefly, $25 \mu \mathrm{l}$ of haemocyte suspensions were incubated with serially diluted two-fold in TBS-I ${ }^{+}$pH 7.4 buffer or PBS pH 7.8 in flat- bottomed microtitre plates (Nunc Roskilde, Denmark), and $25 \mu \mathrm{l}$ of buffer or serum treated heat inactivated yeast $S$. cereviceace was added, mixed, and incubated for $30 \mathrm{~min}$ at $25^{\circ} \mathrm{C}$. This suspension was smeared on the glass slide, after drying, fix the smear with ethanol. Phagocytised yeast was viewed at $40 \mathrm{X}$ magnification and counted under microscope (Nikon, Japan). Alternatively formalin killed yeast S. cereviceace also used for the phagocytosis assay, after $24 \mathrm{hr}$ incubation the pellets were collected and washed with potassium or sodium diphosphate buffer and the suspension was used for the phagocytic assay.

\section{Encapsulation and cell adhesion}

In encapsulation response $25 \mu \mathrm{l}$ of plasma samples from $F$. indicus were serially diluted two-fold in $\mathrm{TBS} / \mathrm{Ca}_{2}{ }^{+} \mathrm{pH} 7.4$ buffer in flatbottomed micro titre plates. To each well, $25 \mu$ of sepharose beads ( 6 $\mathrm{mg} / \mathrm{ml}$ in TBS- $\mathrm{I}^{+} \mathrm{pH}$ 7.4) and $25 \mu \mathrm{l}$ of haemocyte lysate supernatant were added, mixed, and incubated for $45 \mathrm{~min}^{-1} \mathrm{~h}$ at $25^{\circ} \mathrm{C}$. Finally, $25 \mu \mathrm{l}$ of this mixture was taken for the microscopic studies. Positive control was made without sample plasma or HLS (Haemolystae), sepharose beads (Sepharose CL6B, CM Sepharose and Sodium alginate beads). Encapsulated beads with haemocytes were seen under the microscope (Nikon, Japan) and calculated.

\section{Statistical analysis}

Each experiment was performed 3 to 10 times using samples from different preparations. Differences between control and experimental values were statistically analysed for significance by the paired-sample Student $t$-test.

\section{Results}

\section{Total haemocyte count}

Total haemocyte counts were varied remarkably among individuals, ranging from $\sim 5.8$ to $12 \times 10^{5}$ cells $/ \mathrm{mm}^{3}$ of haemolymph (Figure 1 ). The resulting mean indicates the circulating haemocytes number around $6.0\left(\times 10^{6}\right)$ cells/ml of haemolymph $(\mathrm{n}=6)$ F. indicus.

\section{ProPO activity}

PO activity of plasma, haemocyte lysate and haemolymph of $F$ indicus were determined. The results indicate that the plasma showed highest PO activity. In addition, increase in the concentration of laminarin like PAMPs led to a parallel increase in PO activity in $F$. indicus haemocytes (Figure 2).

\section{Agglutination and agglutination inhibition assays}

Plasma, supernatant and pellet samples of $F$. indicus was found

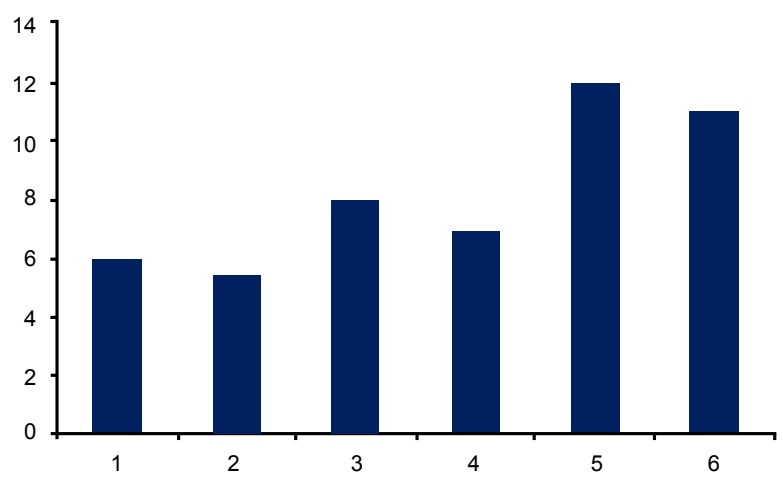

Figure 1: THC of Indian white shrimp F. indicus (6 nos). 


\begin{tabular}{|l|l|l|l|l|}
\hline S.No & RBC types and Yeast & Supernatant & Plasma & Pellet \\
\hline 1 & Human A & 45 & 38 & 15 \\
\hline 2 & Human B & 22 & 32 & 14 \\
\hline 3 & Human O & 15 & 25 & 10 \\
\hline 4 & Human AB & 23 & 20 & 10 \\
\hline 5 & Mice & 15 & 15 & 12 \\
\hline 6 & Rat & 15 & 14 & 16 \\
\hline 7 & Yeast (Native) & 28 & 20 & 15 \\
\hline
\end{tabular}

F. indicus plasma was agglutinated with different types of RBCs like human, mouse, rat, rabbit and chicken erythrocytes.

Table 1: Agglutinating activity profile of various plasma fractions of F.indicus against mammalian RBC types and yeast cells.

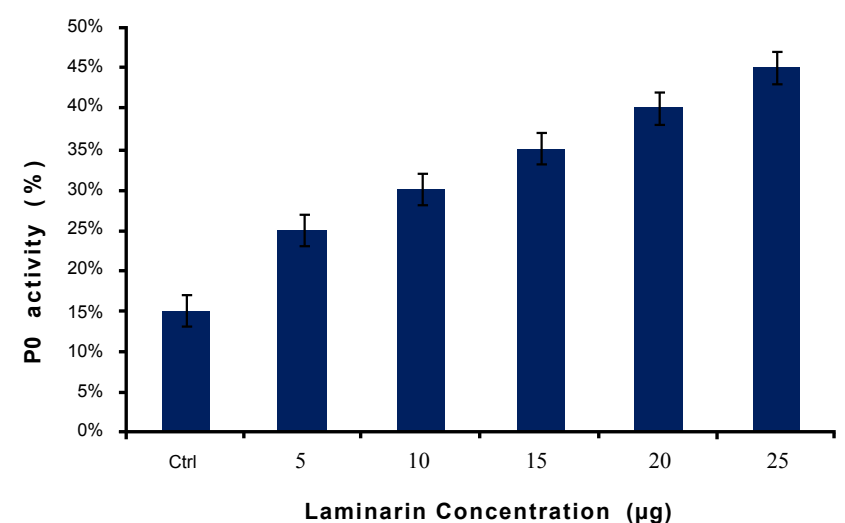

Figure 2: Dose-dependent enhancement of $\mathrm{PO}$ activity in a plasma fraction (pellet) of $F$. indicus. Activation of phenoloxidase was observed with the respective dosage of laminarin.

to agglutinate in all types of the human, mouse and rat erythrocytes. Results indicate that strongest agglutination titre was found in human erythrocytes (Figure 3A, Table 1) and towards yeast $S$. cereviceace (Figure $3 \mathrm{~B}$ ). The binding specificity of plasma was examined by HA inhibition assays using several carbohydrates and glycoproteins. Among the twenty one carbohydrates tested, only ten showed the agglutination inhibition with the plasma of $F$. indicus (Table 2). Monosaccharides and disaccharides had highest binding specificity in inhibition comparing with polysaccharides. Among the monosaccharides, primary sugars showed highest value $(100 \mathrm{mM})$ in agglutination inhibition, and $\mathrm{N}$-acetyl derivatives, showed lower values $(32 \mathrm{mM})$. Tests with amino sugars posses the agglutination inhibition at the low level $50 \mathrm{mM}$ (Table 3) when compared to monosaccharides.

\section{In vitro phagocytic assays}

Haemocyte monolayers (HML) comprising fully haemocytes were rinsed and spread over the surface with iso-osmotic TBS-V $\left(\mathrm{Ca}^{2++}, \mathrm{pH}\right.$ 7.8), all haemocytes tends to get a round configuration within $5 \mathrm{~min}$. The rounded haemocytes were incubated for $10 \mathrm{~min}$ with yeast cells suspended in buffer and showed the attachment of few yeast cells to the surface of the haemocyte, free yeast cells were found in monolayer (Figure 4A) (Table 4). Haemocyte monolayer conditions, free and haemocyte attached yeast cells were retractile, surrounded by bright rings and were clearly visible under phase optics. It suggests that $F$. indicus haemocytes involved in the phagocytic activity with yeast cells. Moreover, the haemocytes had the clear cut protecting activity against the foreign particle enter in the host. Upon extension of the incubation time for up to $10 \mathrm{~min}$ with yeast cells, it was vividly notable that several haemocytes contained up to 5 yeast cells intracellular,

\begin{tabular}{|c|c|c|}
\hline $\mathrm{CHO}$ tested & $\begin{array}{l}\text { Maximum } \\
\text { concentration(mM) }\end{array}$ & $\begin{array}{l}\text { Minimum } \\
\text { inhibitory } \\
\text { concentration }(\mathrm{mM})\end{array}$ \\
\hline \multicolumn{3}{|l|}{ Monosaccharides } \\
\hline D-Glucose & 200 & 100 \\
\hline D-Galactose & 200 & 100 \\
\hline D-Mannose & 200 & 100 \\
\hline D-Fructose & 200 & 100 \\
\hline L-Fructose & 200 & 100 \\
\hline De-Oxy sugars & & 100 \\
\hline 2-Deoxy D-Glucose & 200 & 100 \\
\hline 2-Deoxy D-Galactose & 200 & 100 \\
\hline \multicolumn{3}{|l|}{ Acidic Sugars } \\
\hline D-Glucouronic acid & 200 & 25 \\
\hline Glucouronic acid & 200 & 28 \\
\hline \multicolumn{3}{|l|}{ N-Acetyl sugars } \\
\hline GluNAC & 200 & 32 \\
\hline GaINAC & 200 & 32 \\
\hline ManNAC & & 35 \\
\hline \multicolumn{3}{|l|}{ Amino sugars } \\
\hline Gal N & 200 & 50 \\
\hline Glu N & 200 & 50 \\
\hline Man N & 200 & 50 \\
\hline \multicolumn{3}{|l|}{ Glycosides } \\
\hline \multicolumn{3}{|l|}{ Methyl- $\beta-D$} \\
\hline Glucopyronoside & 200 & 25 \\
\hline $\begin{array}{l}\text { p-Nitrophenyl- } \beta \text { - } \\
\text { DGlucopyranoside }\end{array}$ & 200 & 25 \\
\hline \multicolumn{3}{|l|}{ Disaccharides } \\
\hline D-Maltose & 200 & 100 \\
\hline Sucrose & 200 & 100 \\
\hline PAlatinase & 200 & 50 \\
\hline D-Lactose & 200 & 50 \\
\hline D-Melibiose & 200 & 50 \\
\hline
\end{tabular}

The assay was repeated five times for each carbohydrate with identical results Table 2: Inhibition of agglutinating activity (titre=4) of plasma from the $F$. indicus by various carbohydrates.

thereby demonstrating phagocytic activity of $F$. indicus haemocytes in vitro (Figure $4 \mathrm{~B}$ ). While testing with $F$. indicus haemocytes, the intracellular (Ingested) yeast cells appeared darker and markedly lost their surrounding bright rings as compared with free or extracellularly attached yeast cells. Thus, the apparent differences enabled easy and unambiguous determination of the ingestion (like melanisation) of yeast cells (Figure 4C).

\section{Encapsulation and cell adhesion}

F. indicus haemocytes having the capacity to encapsulate chromatography beads with different surface characteristics were tested in vitro. Among the different bead tested the haemocytes showed encapsulation response only against sepharose CL6B beads (Figure 5) in test.

\section{Discussion}

In arthropods, phenoloxidase has usually been described as inactive within haemocytes, only being activated with serine proteases, LGBP and other PGRPs once released into the haemolymph Soderhall [25]. In the current study, results indicate that phenoloxidase in $F$. indicus can be activated by laminarin like Pattern Associated Molecular Patterns (PAMP) in in vitro. In this study normal level of haemocyte count in the 


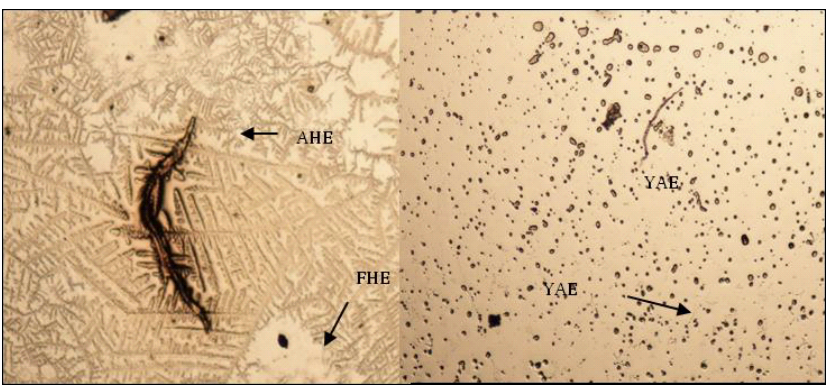

Figure 3: Phase contrast and differential interference contrast (DIC) photomicrographs of live hemocytes of Findicus (A, B). Phase contrast images of hemocytes showing agglutination with HB RBC. Note that the Agglutinated erythrocytes \& haemocytes (AHE) appeared darker and markedly lost their surrounding bright rings as compared to free (FHE) or attached (YAE) erythrocytes. DIC images of the same area.

\begin{tabular}{|l|l|l|}
\hline Polysaccharides & $\begin{array}{l}\text { Max.Concentration } \\
(\mathrm{mg} / \mathrm{ml})\end{array}$ & $\begin{array}{l}\text { Minimum Inhibitory } \\
\text { Concentration }(\mathrm{mg} / \mathrm{ml})\end{array}$ \\
\hline Laminarin & 1 & 0.5 \\
\hline Mannan & 1 & 0.58 \\
\hline Dextran & 1 & 0.83 \\
\hline Inulin & 2 & 0.6 \\
\hline Coliminic Acid & 5 & 0.6 \\
\hline
\end{tabular}

The assay was repeated three times for each polysaccharide with identical results using samples from different preparations

Table 3: Inhibition of agglutinating activity (titre $=4$ ) of plasma from the $F$. indicus by various polysaccharides.

\begin{tabular}{|l|l|l|l|}
\hline S.no & RBC types and Yeast & Ctrl & Test \\
\hline 1 & Haemolymph & $0.022 \pm 0.001$ & $0.035 \pm 0.002$ \\
\hline 2 & Plasma & $0.018 \pm 0.002$ & $0.019 \pm 0.002$ \\
\hline 3 & Pellet & $0.008 \pm 0.002$ & $0.038 \pm 0.001$ \\
\hline
\end{tabular}

Data represent median values from 10 replicates for each RBC type and yeas cells.

Plasma obtained from the clarified plasma previously incubated with laminarin Pellet (dissolved and dialysed against TBS-I) was collected after centrifugation $\left(25,000 \times \mathrm{g}, 15 \mathrm{~min}, 4^{\circ} \mathrm{C}\right)$ of supernatant previously incubated with laminarin.

Table 4: Phagocytic activity in different plasma fractions of $F$. indicus.

Indian white shrimp F.indicus was found to be 1.04 to $12.21 \times 10^{5}$ cells/ $\mathrm{mm}^{3}$. Previous reports showed the high disparity in total haemocyte count (THC) of different crustacean species. For example, in Penaeus californiensis THC level was about $11 \times 10^{3}$ cells $/ \mathrm{mm}^{3}$ (43), Penaeus japonicas $5-14 \times 10^{6}$ cells $/ \mathrm{mm}^{3}$ [26], Penaeus setiferus $8.9 \times 10^{6}$ cells $/ \mathrm{mm}^{3}$ [27]. These findings propose us the difference in the THC counts in crustaceans showing the variation in the cellular immune responses such as phagocytosis and encapsulation. Phenoloxidase activity in both cell-free haemolymph and haemocytes of F.indicus was observed. Cellular haemolymph fraction is of specific interest because it appears to be strongly associated with defence against the pathogen. In the present study plasma of $F$. indicus showed reactivity with different RBC types with highest reactivity against human RBC. Similar results were reported in mollusc [28-32]. Plasma from F.indicus was found to agglutinate all the RBCs (Human A, Human B, Mice, Human O, Human $\mathrm{AB}$, Rat and Yeast) tested. The strongest agglutination titre was observed in F. indicus haemocytes against human RBCs, yeast $S$. cereviceace and it was viewed under light microscope. Similarly insects showed the agglutination activity with human RBCs (1998). It may be due to pattern recognition molecules occurrences in haemolymph.

In the present study, the differential profile of agglutinating activity of plasma, and agglutination inhibition were tested with 21 carbohydrates, only ten inhibited the agglutinating activity of $F$. indicus haemocytes. Monosaccharides and disaccharides had the highest binding specificity in inhibition. In contrast, some $\mathrm{N}$-acetyl derivatives, namely, $\mathrm{N}$-acetyl neuraminic acid (NeuAc), N-acetyl glucosamine (GlcNAc) and $\mathrm{N}$-acetyl galactosamine (GalNAc) inhibited the HA activity of plasma even at very low concentrations $(32 \mathrm{mM})$. Amino sugars and acidic sugars showed the agglutination inhibition at a low concentration level of $50 \mathrm{mM}$, while testing the six polysaccharides. Phagocytosis does not appear to be solely dependent on these factors, since a few studies with crustacean haemocytes morphotypes such as agranular or hyaline cells have shown that they are capable of responding to bacterial cells in the absence of detectable levels of PO or its precursor [32-34]. Phagocytic activity in $F$. indicus was tested using yeast, yeast cells appeared darker and markedly lost their surrounding bright rings as compared with free or extracellular attached yeast cells.

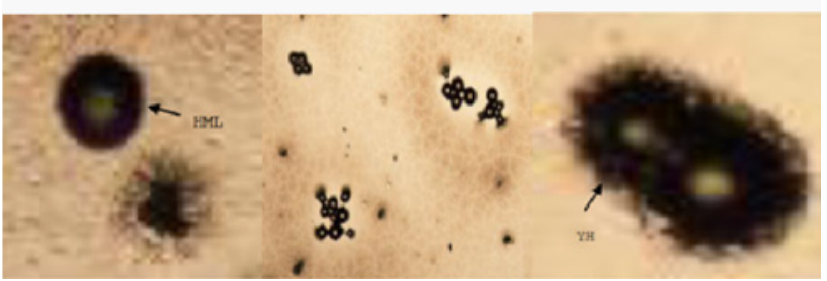

Figure 4: Rounded haemocytes were incubated with yeast cells and the attachment with few yeast cells to haemocyte surface, free yeast cells were found in monolayer (Haemocyte monolyer HML) (A). F. indicus haemocyte attached with 5 yeast cells intracellularly that were surrounded by bright rings and visible under phase optics (B). Ingested yeast cells emerge darke and lost their surrounding bright rings obviously as compared with free or extracellularly attached yeast cells (yeast haemocytes $-\mathrm{YH})(\mathrm{C})$.

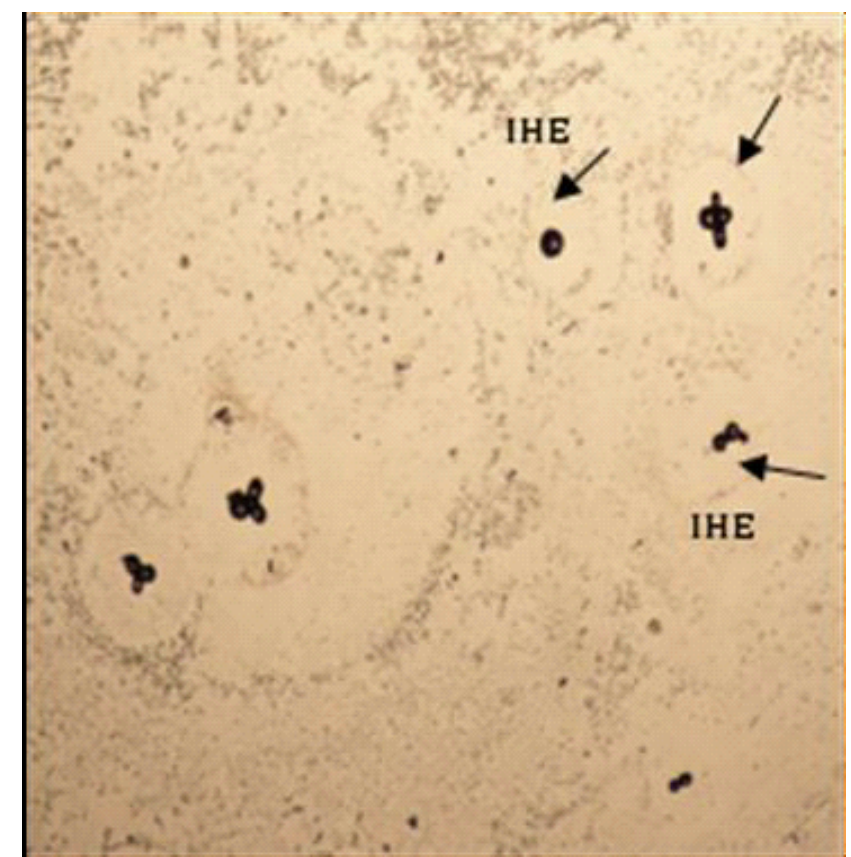

Figure 5: Encapsulation of chromatographic beads DEAE-sepharose was encapsulated with the $F$. indicus haemocytes that encapsulated beads were marked as (IHE) that was shown. Note: All free, attached and ingested erythrocytes are clearly discernible. 
Citation: Sivakamavalli J, Rajakumaran P, Vaseeharan B (2012) Prophenoloxidase and Immune Indices of Indian White Shrimp Fenneropenaeus Indicus. J Aquacult Res Dev 3:148 doi:10.4172/2155-9546.1000148

In the present study, encapsulation response of $F$. indicus haemocytes with three types of chromatography beads was tested, encapsulation response only noted against sepharose CL6B beads. The interaction of haemocytes with beads based on surface charges has been reported in insects [35-37], crustaceans [38] and Mollusca [39,40]. In conclusion, the present study reports the ProPo activating system, function and the immune indices of $F$. indicus leads to the understanding of the innate immunity. Further molecular biological studies are needed to confirm the intruding mechanism of Propo system.

\section{Acknowledgement}

The authors acknowledge University Grants Commission (UGC), New Delhi, India for providing financial support under the grants code :- F.No. 36-5/2008(SR) 2009-2011.

\section{References}

1. Wang W, Gu Z (2002) Rickettsia- like organism associated with tremor disease and mortality of the Chinese mitten crab Eriocheir sinensis. Dis Aquat Org 48: 149-153.

2. Xu HS, Shu MA, Zhan XA, Wang SX (2002) Identification of Vibrio parahaemolyticus isolated from cultured Eriocheir sinensis and pathogenicity of its extracellular products. Journal of Fisheries of China 26: 357-362.

3. Zhang SY, Zhang JH, Huang CH, Bonami JR, Shi ZL (2002) Preliminary studies on two strains of reovirus from crab Eriocheir sinensis. Virologica Sinica 17 263-265.

4. Liu CH, Cheng W, Kuo CM, Chen JC (2004) Molecular cloning and characterisation of a cell adhesion molecule, peroxinectin from the white shrimp Litopenaeus vannamei. Fish Shellfish Immunol 17: 13-26.

5. Lo CF, Chang YS, Peng SE, Kou GH (2003) Major viral diseases of Penaeus monodon in Taiwan. J Fish Soc Taiwan 30:1-13.

6. Hoffmann JA, Kafatos FC, Janeway CA Jr, Ezekowitz RAB (1999) Phylogenetic Perspectives in innate immunity. Science 284: 1313-1318.

7. Medzhitov R, Janeway C Jr (2000) Innate immune recognition: mechanisms and pathways. Immunol Rev 173: 89-97.

8. Medzhitov R, Janeway CA (2002) Decoding the patterns of self and non self by the innate immune system. Science 296: 298-300.

9. Medzhitov R, Janeway CA (2000) Innate immunity. N Engl J Med 343: 338-344

10. Lee SY, Wang R, Soderhall K (2000) A lipopolysaccharide- and $\beta-1,3$-glucan binding protein from hemocytes of the freshwater crayfish Pacifastacus leniusculus. J Biol Chem 275: 1337-1343.

11. Soderhall K, Cerenius $L$ (1998) Role of the prophenoloxidase-activating system in invertebrate immunity. Curr Opin Immunol 10: 23-28.

12. Sritunyalucksana K, Soderhall K (2000) The proPO and clotting system in crustaceans. Aquaculture 191: 53-69.

13. Duvic B, Soderhall K (1992) Purification and partial characterization of a beta1,3-glucan-binding-protein membrane receptor from blood cells of the crayfish Pacifastacus leniusculus. Eur J Biochem 207: 223-228.

14. Soderhall K, Vey A, Ramstedt M (1984) Haemocyte lysate enhancement of fungal spore encapsulation by crayfish haemocytes. Dev Comp Immunol 8: 23-29.

15. Dziarski R (2004) Peptidoglycan recognition proteins (PGRPs). Mol Immuno 40: $877-886$

16. Zhang R, Cho HY, Kim HS, Ma YG, Osaki T, et al. (2003) Characterization and properties of a 1,3-beta-D-glucan pattern recognition protein of Tenebrio molitor larvae that is specifically degraded by serine protease during prophenoloxidase activation. J Biol Chem 278: 42072-42079.

17. Lin YC, Vaseeharan B, Chen JC (2008) Identification and phylogenetic analysis on lipopolysaccharide and beta-1,3-glucan binding protein (LGBP) of kuruma shrimp Marsupenaeus japonicus. Dev Comp Immunol 32: 1260-1269.

18. Bilej M, De Baetselier P, Van Dijck E, Stijlemans B, Colige A, et al. (2001) Distinct carbohydrate recognition domains of an invertebrate defense molecule recognize Gram-negative and Gram-positive bacteria. J Biol Chem 276: 45840 45847.
19. Cerenius L, Liang Z, Duvic B, Keyser P, Hellman U, et al. (1994) Structure and biological activity of a 1,3- $\beta$-D-glucan binding protein in crustacean blood. J Bio Chem 269: 29462-29467.

20. Yu XQ, Kanost MR (2003) Manduca sexta lipopolysaccharide-specific immulectin-2 protects larvae from bacterial infection. Dev Comp Immunol 27 189-196.

21. Chen C, Rowley AF, Ratcliffe NA (1998) Detection, purification by immunoaffinity chromatography and properties of $\beta$-1,3-glucan-specific lectins from the sera of several insect species. Insect Biochemistry and Mol Biol 28: 721-731.

22. Nowak TP, Haywood PL, Barondes SH (1976) Developmentally regulated lectin in embryonic chick muscle and a myogenic cell line. Biochem Biophys Res Commun 68: 650-657.

23. Maheswari R, Mullainathan P, Arumugam M (1997) Characterization of natural haemoagglutinin with affinity for acetylated aminosugars in the serum of the marine, Penaeus indicus. Fish Shellfish Immunol 7: 17

24. Arumugam M, Romestand B, Torreilles J, Roch $P$ (2000) In vitro production of superoxide and nitric oxide (as nitrite and nitrate) by Mytilus galloprovincialis haemocytes upon incubation with PMA or laminarin or during yeast phagocytosis. Eur j cell biol 79: 513-519.

25. Soderhall K (1992) Biochemical and molecular aspects of cellula communication in arthropods. Bolletino di Zoologia 59: 141-151.

26. Tsing A (1989) Hemocytes of penaeid and palaemonid shrimps: Morphology cytochemistry and hemograms. J Invert Pathol 53: 64-77.

27. Yeager JF, OE Tauber (1935) On the hemolymph cell counts of some marine invertebrates. Biol Bull 69: 66-70.

28. Vasta GRT, Cheng C, Marchalonis J (1984) A lectins on the haemocytes membrane of the oyster (Crassostrea viriginica). Cellular Immunology 88: 475 488.

29. Mullainadhan $P$, Renwrantz $L$ (1986) Lectin-dependent recognition of foreign cells by haemocytes of the mussel, Mytilus edulis. Immunobiology 171: 263 273.

30. Odo S, Kamino K, Kanai S, Maruyama T, Haryama S (1995) Biochemica characterization of $\mathrm{Ca}^{2++}$ dependent lectin from the haemocytes of a photosymbiotic marine biovalve. Tridacna derasa (Roding). J Biol Chem 117: 965-973.

31. Arreguin-Espinosa R, Arreguin-Lozano B (1997) Biochemical properties of haemagglutinins in the mollusk Pomacea flagellata. Biochem Mol Biol Int 43 1241-1251.

32. Soderhall K, Smith V (1988) The Prophenoloxidase activating cascade as recognition system in arthropod". New York, Wiley Interscience Publications 251-285.

33. Thornqvist PO, Johansson MW, Soderhall K (1994) Opsonic activity of cell adhesion proteins and beta-1,3-glucan binding proteins from two crustaceans. Dev Comp Immunol 18: 3-12.

34. Barracco MA, Steil AA, Gargioni R (1993) Morphological characterization of the hemocytes of the pulmonate snail Biomphalaria tenagophila. Mem Inst Oswaldo Cruz 88: 73-83

35. Ratner S, Vinson SB (1983) Encapsulation reactions in vitro by haemocytes of Heliothis virescens. J Insect Physiology 29: 855-863.

36. Pech LL, Strand MR (1996) Granular cells are required for encapsulation of foreign targets by insect haemocytes. J Cell Sci 109: 2053-2060.

37. Martin GG, Graves BL (2005) Fine structure and classification of shrimp hemocytes. J Morphol 185: 339-348.

38. Lavine MD, Strand MR (2001) Surface characteristics of foreign targets that elicit an encapsulation response by the moth Pseudoplusia includens. J Insect physiol 47: 965-974.

39. Persson M, Vey A, Soderhall K (1987) Encapsulation of foreign particles in vitro by separated blood cells from crayfish, Astacus leptodactylus. Cell and Tissue Research 247: 409-415.

40. Sminia T, Borghart-Reinders E, Van de Linde AW (1974) Encapsulation of foreign materials experimentally introduced into the fresh water snail Lymnaea stagnalis. An electron microscopic and autoradiographic study. Cell Tissue Res 153: 307-326. 